\title{
Mediterranean Outflow Water variability during the Early Pleistocene
}

\author{
Stefanie Kaboth ${ }^{1,2}$, Patrick Grunert ${ }^{3}$, and Lucas Lourens ${ }^{2}$ \\ ${ }^{1}$ Department of Earth Sciences, National Taiwan University, No 1. Sec. 4 Roosevelt Road, 106 Taipei City, Taiwan \\ ${ }^{2}$ Department of Earth Sciences, Utrecht University, Heidelberglaan 2, 3584 CS, Utrecht, the Netherlands \\ ${ }^{3}$ Institute of Earth Sciences, University of Graz, NAWI Graz, Heinrichstraße 26, 8010 Graz, Austria
}

Correspondence to: Stefanie Kaboth (stefaniekaboth@ntu.edu.tw)

Received: 30 January 2017 - Discussion started: 16 February 2017

Revised: 5 July 2017 - Accepted: 15 July 2017 - Published: 17 August 2017

\begin{abstract}
Gaining insights into the evolution of Mediterranean Outflow Water (MOW) during the Early Pleistocene has been so far hampered by the lack of available palaeoclimatic archives. Here we present the first benthic foraminifera stable oxygen and carbon isotope records and grain-size data from IODP Expedition 339 Site U1389 presently located within the upper core of the MOW in the Gulf of Cadiz for the time interval between 2.6 and $1.8 \mathrm{Ma}$. A comparison with an intermediate water mass record from the Mediterranean Sea strongly suggest an active MOW supplying Site U1389 on glacial-interglacial timescales during the Early Pleistocene. We also find indication that the increasing presence of MOW in the Gulf of Cadiz during the investigated time interval aligns with the progressive northward protrusion of Mediterranean sourced intermediate water masses into the North Atlantic, possibly modulating the intensification of the North Atlantic Meridional Overturning Circulation at the same time. Additionally, our results suggest that MOW flow strength was already governed by precession and semi-precession cyclicity during the Early Pleistocene against the background of glacial-interglacial variability.
\end{abstract}

\section{Introduction}

The Mediterranean Outflow Water (MOW) is a distinct hydrographic feature at intermediate water depths in the Gulf of Cadiz, distinguished from other ambient North Atlantic water masses by its warm and saline character (Fig. 1a; Ambar and Howe, 1979; Bryden et al., 1994; Bryden and Stommel, 1984). In the modern hydro-climatic setting of the Mediterranean Sea the MOW is predominately sourced by Levantine Intermediate Water $(\sim 70 \%)$, formed in the eastern Mediterranean Basin, and variable parts of Western Mediterranean Deep Water (WMDW) originating in the Alboran and Tyrrhenian Sea (Fig. 1b and c; Millot, 2009, 2014; Millot et al., 2006). After exiting the Strait of Gibraltar, the MOW plume cascades down the continental slope due to its increased density (Ambar and Howe, 1979; HernandezMolina et al., 2006, 2014a; Mulder et al., 2006). In the Gulf of Cadiz, MOW follows the topography of the continental shelf in two major flow cores at $800-1400 \mathrm{~m}$ water depth (lower MOW core) and 500-700 $\mathrm{m}$ water depth including our study area (upper MOW core, Fig. 1a) (Baringer and Price, 1997; Borenäs et al., 2002; Hernández-Molina et al., 2013). After exiting the Gulf of Cadiz, most of MOW flows north along the European continental margin until it mixes with the North Atlantic Current at Rockall Plateau (HernandezMolina et al., 2014b). Beyond the Mediterranean region, MOW has been acknowledged as an important modulator of the North Atlantic salt budget, with previous research suggesting that the absence of MOW may reduce Atlantic Meridional Overturning Circulation (AMOC) by as much as $15 \%$ compared to modern conditions (Rogerson et al., 2006). Despite its potential cosmopolitan significance, the palaeoceanographic history of MOW has so far been only studied for the Pliocene (Khelifi et al., 2009; Khélifi and Frank, 2014) and during the Late and Middle Pleistocene (Bahr et al., 2015; Kaboth et al., 2016, 2017; Llave et al., 2006; Schönfeld, 2002; Schönfeld and Zahn, 2000; Toucanne et al., 2007; Voelker et al., 2006). In this light, the reconstruction of MOW variability might be particularly interesting in the 

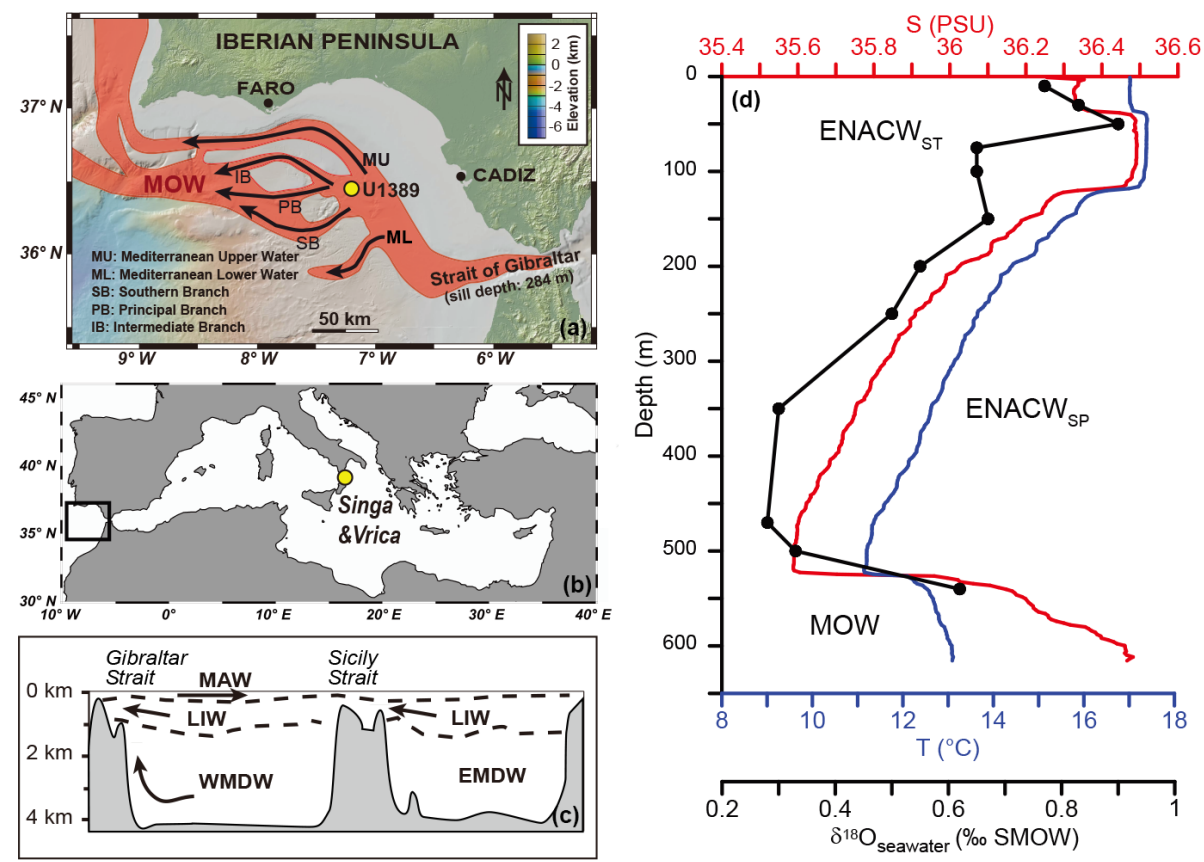

Figure 1. (a) Study area with illustration of modern MOW pathways modified after (Bahr et al., 2015). Site location of U1389 (yellow dot) is marked. (b) Overview map of the Mediterranean Sea. Location of the Singa and Vrica sections in Italy (yellow dot) are marked. Black square indicates Gulf of Cadiz study area. (c) Water mass circulation in the Mediterranean Sea (modified after Cramp and O'Sullivan, 1999). MAW: mixed Atlantic surface water; LIW: Levantine Intermediate Water; EMDW: Eastern Mediterranean Deep Water; WMDW: Western Mediterranean Deep Water. (d) CTD depth profile of temperature (red line) and salinity (blue line) at Site U1389 derived from the

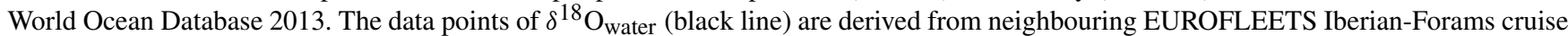
site IB-F9 $\left(36^{\circ} 48.40^{\prime} \mathrm{N}, 7^{\circ} 42.85^{\prime} \mathrm{W}\right)$ (Voelker et al., 2015). NACW st $_{\text {: North Atlantic Central Water of subtropical origin; NACW }}$ : North Atlantic Water of subpolar origin; MOW: Mediterranean Outflow Water.

broader view of the Pliocene-Pleistocene climate transition. The Early Pleistocene period spans the transition from the preceding Pliocene climate optimum with limited ice sheets in the Northern Hemisphere to the cooler Middle and Late Pleistocene climate with rapidly developing continental ice growth in both hemispheres (Raymo et al., 1992; Shackleton and Hall, 1984). Throughout the Early Pleistocene, however, an interruption of the long-term Northern Hemisphere ice volume increase can be observed in concert with a seasurface temperature stabilization in the high-latitude North Atlantic cooling trend (Bell et al., 2015). It was suggested that these changes relate to an increase in AMOC strength and, by extension, an increase in northward heat transport (Bell et al., 2015). Here we elaborate on the possible role of MOW on North Atlantic palaeoceanographic changes during the Early Pleistocene climate transition by investigating the benthic foraminifera stable oxygen and carbon isotopes and grain sizes from IODP 339 Site U1389, located on the upper slope of the Gulf of Cadiz (see Fig. 1a) for two time intervals: 2.6 and $2.4 \mathrm{Ma}$ and 2.1 and $1.8 \mathrm{Ma}$. We have compared our new data with the benthic stable isotope record of the Singa/Vrica sections in Calabria (Italy), representing the intermediate water mass end-member of the Mediterranean Sea (Lourens et al., 1996a, b; unpublished data) that serves as a reference for the source region of MOW during the Early Pleistocene (Fig. 1b). Our results bridge the gap in our understanding of MOW variability between the more widely researched Pliocene and Late and Middle Pleistocene. We aim to shed new light on MOW variability during the Early Pleistocene by analysing hydrographic changes within the Mediterranean source region, investigating the low-latitude control of MOW against the background of dominant obliquity controlled glacial-interglacial cyclicity, and documenting the potential influence of MOW variability on long-term climatic oscillations in the North Atlantic.

\section{Material and methods}

\subsection{Site U1389}

Integrated Ocean Drilling Program (IODP) Site U1389 $\left(36^{\circ} 25.515^{\prime} \mathrm{N}, 7^{\circ} 16.683^{\prime} \mathrm{W}\right)$ was drilled in December 2011 and January 2012 during Expedition 339 (Stow et al., 2013). It is located on the southern Iberian Margin $\sim 90 \mathrm{~km}$ west of the city of Cadiz and perched on the northwest side of the Guadalquivir diapiric ridge at $644 \mathrm{~m}$ water depth (Fig. 1a). At present, IODP Site U1389 is at depth directly influenced by the upper MOW core (Hernández-Molina et al., 2013). In its 
modern configuration MOW ( $>36 \mathrm{PSU}, \sim 13^{\circ} \mathrm{C}$ ) is sourced predominately of intermediate water masses from the eastern Mediterranean Sea (Fig. 1d; Ambar and Howe, 1979; Millot, 2009, 2014; Millot et al., 2006). The water column above the MOW is influenced by subtropical water masses $\left(14-16^{\circ} \mathrm{C}\right.$; $\sim 36.2 \mathrm{PSU}$ ) originating from the northern boundary of the eastern Azores Current branch (Peliz et al., 2009, 2005). During spring and summer, colder and fresher subsurface water masses can be traced along the upper and middle slope as indicated by a salinity minimum above the MOW (see Fig. 1d) linked to the seasonal upwelling systems along the Iberian Margin (Fiúza et al., 1998).

For the present study we analysed 423 samples from Site U1389 Hole E which cover the Early Pleistocene (2.6 to $1.8 \mathrm{Ma}$ ) time interval at $30 \mathrm{~cm}$ intervals between 549.8 and 706.35 mbsf. An expanded hiatus at Hole U1389E between 2.1 and $2.4 \mathrm{Ma}(\sim 622-644 \mathrm{mbsf})$ has been initially related to a phase of highly active MOW (Hernández-Molina et al., 2013; Stow et al., 2013). However, more recent findings link this compressional event to tectonically invoked erosion (Hernández-Molina et al., 2015). As a consequence, we present the data split in two intervals (Interval I: 2.6-2.4 Myr; Interval II: 2.1 to $1.8 \mathrm{Myr}$ ).

\subsection{Singa and Vrica}

The Monte Singa IV and Vrica sections of Early Pleistocene age contain sequences of marine marls and sapropelic clay layers, which are exposed in Calabria, southern Italy (Lourens et al., 1992). During the time of deposition, both sections were part of the continental slope bordering the Ionian Basin. The benthic foraminiferal associations represent a deep bathyal palaeo-environment between $\sim 900$ and $\sim 1100 \mathrm{~m}$ water depth (Verhallen, 1991). This suggests that the benthic isotope data derived from these sediment sequences recorded intermediate water mass conditions within the eastern Mediterranean Sea. The biostratigraphic correlation indicates that the Vrica sapropelite suite is equivalent to sequence IV at Monte Singa (Verhallen, 1991; Zijderveld et al., 1991).

\subsection{Stable isotope measurements and interspecies correction}

The freeze-dried sediment samples of Site U1389 were wetsieved into three fractions ( $>150 \mu \mathrm{m}, 150-63 \mu \mathrm{m}, 63-38 \mu \mathrm{m}$ ) and their residues oven-dried at $40{ }^{\circ} \mathrm{C}$. Stable oxygen $\left(\delta^{18} \mathrm{O}\right)$ and carbon $\left(\delta^{13} \mathrm{C}\right)$ isotope analyses were carried out on 4 to 6 specimens of the epifaunal living foraminiferal species Planulina ariminensis and Cibicidoides ungerianus from the $>150 \mu \mathrm{m}$ size fraction. All selected specimens were crushed, sonicated in ethanol, and dried at $35^{\circ} \mathrm{C}$. Stable isotope analyses were carried out on a CARBO-KIEL automated carbonate preparation device linked to a Thermo-Finnigan MAT253 mass spectrometer at Utrecht University. The precision of the measurements is $\pm 0.08 \%$ for $\delta^{18} \mathrm{O}$ and \pm 0.03 for $\delta^{13} \mathrm{C}$. The results were calibrated using the international standard NBS-19 and the in-house standard NAXOS. Isotopic values are reported in standard delta notation $(\delta)$ relative to the $\mathrm{Vi}$ enna Pee Dee Belemnite (VPDB). P. ariminensis was absent in 100 samples; resulting gaps were filled with $C$. ungerianus values corrected for interspecies isotopic offsets. The calculation of the interspecies offset is based on 62 paired isotope measurements of both benthic species. The $\delta^{18} \mathrm{O}$ interspecies offset was determined by applying a least squares linear regression equation (Fig. 2). The Pearson correlation coefficient $\left(R^{2}\right)$ between both species shows high correlation of 0.80 for $\delta^{18} \mathrm{O}$ (Fig. 2a). The calculated slope of this relationship is $\sim 1$ with a $y$ intercept of $+0.10 \%$, which is minor considering the analytical error of the measurements of $\pm 0.08 \%$. This suggests a comparable oxygen isotope fractionation between $P$. ariminensis and $C$. ungerianus. A similar behaviour has been postulated for $P$. ariminensis and other Cibicidoides species (Marchitto et al., 2014). These results also align with findings from the same benthic species during the Late and Middle Pleistocene (Kaboth et al., 2017). In contrast, the $\delta^{13} \mathrm{C}$ correlation factor for both benthic species during the Early Pleistocene is insignificant $R^{2}=0.02$ (Fig. 2b). We argue that the high scatter of $C$. ungerianus during the Early Pleistocene might relate to the variability from a preferably epifaunal to a very shallow infaunal life style in correspondence to different nutrient fluxes, oxygenation state, habitat changes etc. This would cause an enhanced variability in the $\delta^{13} \mathrm{C}$ microhabitat offset between both species. Such variability has been observed recently for other Cibicidoides species (Fontanier et al., 2006). In contrast, $P$. ariminensis has been argued to be a reliable recorder of the $\delta^{13} \mathrm{C}$ signal of MOW (Zahn et al., 1987). Rogerson et al. (2011), Schönfeld (2002) and García-Gallardo et al. (2017) further suggested that $P$. ariminensis is a true "elevated" epifaunal living species directly recording MOW properties. Specifically, the influence of remineralization of sedimentary carbon on benthic $\delta^{13} \mathrm{C}$ which may overprint the MOW signal was discussed by Rogerson et al. (2011). The authors considered the $\delta^{13} \mathrm{C}$ signal ambiguous for most benthic foraminifera with the exception of $P$. ariminensis which showed the highest (positive) correlation with MOW flow strength. Therefore, we only present the $\delta^{13} \mathrm{C}$ of $P$. ariminensis, considered a valuable basis for $\delta^{13} \mathrm{C}$ studies of the palaeo-hydrography of the MOW.

\subsection{Grain-size analyses}

The stable isotope sample preparation was used to obtain weight percentages (wt. \%) of the grain-size fractions $>150$, $150-63,63-38$ and $<38 \mu \mathrm{m}$ for the investigated samples were obtained during sample preparation for isotope analyses. We concentrate on the grain-size fraction between 63 and $150 \mu \mathrm{m}$, which has been used previously as an indicator for flow strength changes in the Gulf of Cadiz attributed to 

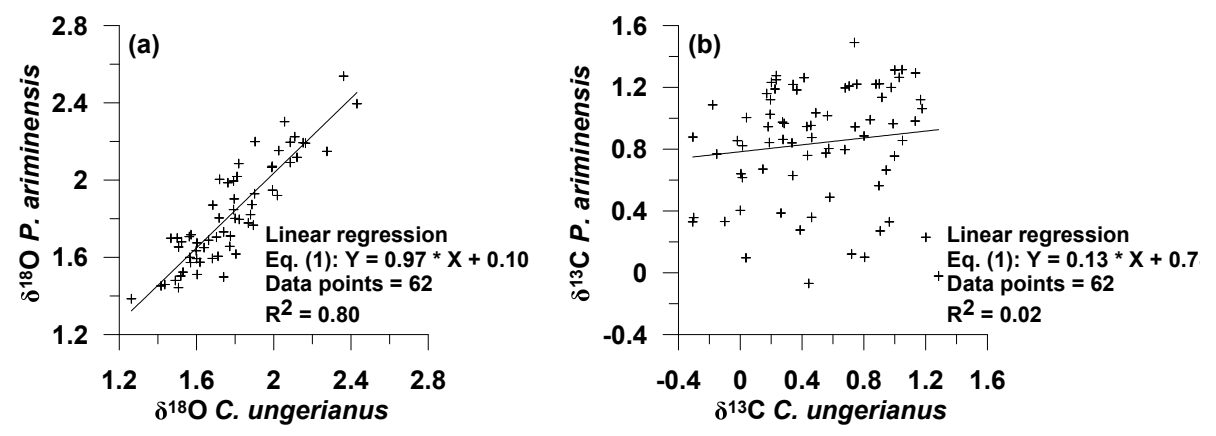

Figure 2. The $\delta^{18} \mathrm{O}$ (a) and $\delta^{13} \mathrm{C}$ (b) interspecies correlation between benthic foraminifera Cibicidoides ungerianus and Planulina ariminensis at Site U1389. Parallel measurements were conducted throughout both investigated intervals. Linear square regression (black line) equation and Pearson correlation coefficient $\left(R^{2}\right)$ are shown.
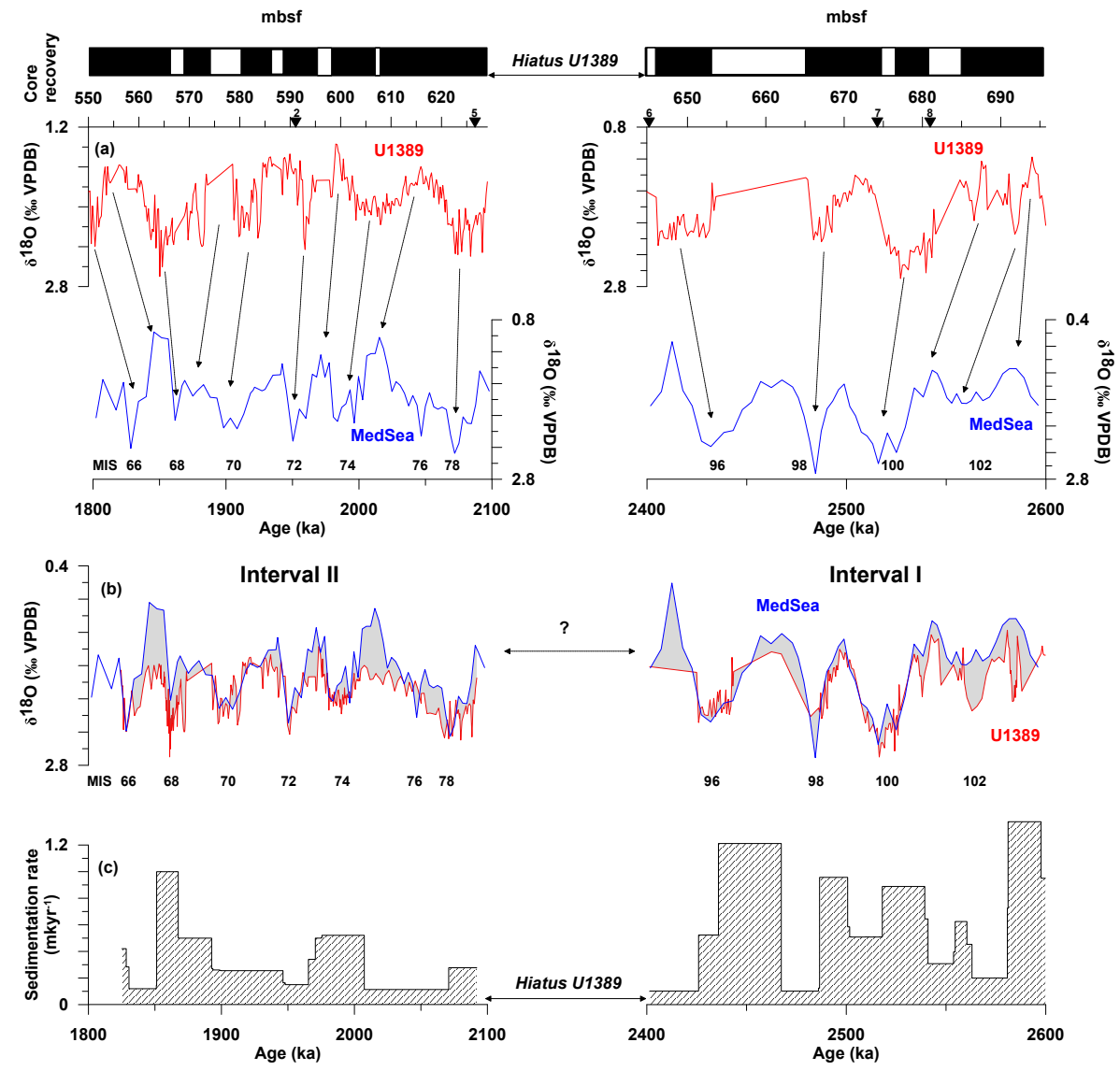

Figure 3. Chronology of Site U1389. Assigned marine isotope stages (MIS) follow Lourens et al. (1996b). (a) Both intervals of the $\delta^{18} \mathrm{O}$ record of Site U1389 on shipboard mbsf scale correlated with the benthic $\delta^{18} \mathrm{O}$ record of the Mediterranean Sea (MedSea stack) after Lourens et al. (1996a, unpublished data). Chronostratigraphy of MedSea stack is based on tuning sapropel midpoints to La2004 $65^{\circ} \mathrm{N}$ summer insolation (Lourens, 2004). Lines with arrows indicate selected tie points used for the age model (a full list of tie points is available in Table 2). Black triangles with numbers indicate biostratigraphic and palaeomagnetic tie points used, as referenced in Table 1. Black and white bar at the top represents core recovery following Hernández-Molina et al. (2013). (b) Comparison of the benthic $\delta^{18} \mathrm{O}$ record of Site U1389 on a new timescale according to our tuning, and the benthic $\delta^{18}$ O MedSea stack on its respective age model (Lourens et al., 2004). (c) Calculated sedimentation rates for Site U1389. 
Table 1. Palaeomagnetic and biostratigraphic tie points used in the primary age model of Site U1389 based on shipboard data following Hernández-Molina et al. (2013) and Stow et al. (2013). 1: Gradstein et al. (2012); 2: Raffi et al. (2006); 3: Lourens et al. (2004); 4: (Grunert et al., 2017).

\begin{tabular}{llrrrr}
\hline No. & Event & Top depth (mbsf) & Bot. depth (mbsf) & Age (ka) & Ref. \\
\hline 1 & Top Olduvai & 542.00 & & 1806 & 1 \\
2 & Bottom Olduvai & & 592.00 & 1945 & 1 \\
3 & Matuyama/Gauss & 699.00 & & 2581 & 4 \\
4 & LO Calcidiscus macintyrei & 510.99 & 515.65 & 1660 & 2 \\
5 & FO Globorotalia inflata & 627.21 & 630.21 & 2090 & 3 \\
6 & LO Globorotalia puncticulata & 645.02 & 646.61 & 2410 & 3 \\
7 & LO Discoaster pentradiatus & 674.25 & 681.98 & 2500 & 2 \\
8 & LO Discoaster scurlus & 681.98 & 693.70 & 2530 & 2 \\
9 & LO Discoaster tamalis & 799.75 & 800 & $2800-2830$ & 4 \\
\hline
\end{tabular}

MOW variability (Rogerson et al., 2005). Even though untreated weight percentages hold a bias, it has been shown for the last climatic cycle that weight percentages mirror major peaks in $\mathrm{Zr} / \mathrm{Al}$ records, considered a reliable recorder of MOW flow strength variability (Bahr et al., 2014) and thus can be used to trace MOW intensity patterns (Kaboth et al., 2016, 2017).

\subsection{Chronology}

Primary age constraints are based on palaeomagnetic and biostratigraphic tie points as listed in Table 1 . The secondary age model follows the visual correlation of the benthic $\delta^{18} \mathrm{O}$ record at Site U1389 to the benthic $\delta^{18} \mathrm{O}$ "MedSea" stack of Lourens et al. (unpublished data) within the investigated time period. The MedSea stack is based on the benthic C. ungerianus $\delta^{18} \mathrm{O}$ values from the Singa and Vrica sections located in Calabria, Italy, derived from the same samples used for the planktic $\delta^{18} \mathrm{O}$ record in Lourens et al. (1996a, personal communication). The stable isotope measurements for the MedSea stack were carried analogous the protocol described in Sect. 2.2 (L. Lourens, personal communication, 2017). The C. ungerianus values of the MedSea stack were adjusted to the $P$. ariminensis-based $\delta^{18} \mathrm{O}$ record at Site $\mathrm{U} 1389$ by applying the interspecies correction equation cited under Sect. 2.2 and Fig. 2a. The Mediterranean Sea stack $\delta^{18} \mathrm{O}$ time series is based on tuning sapropel midpoints to La2004 $65^{\circ} \mathrm{N}$ summer insolation maxima, including a $3 \mathrm{kyr}$ time lag (Lourens, 2004). Monitoring of the sedimentation rate was done to control viability of secondary age model. The designation of MIS stages follows the MedSea stack chronology (Lourens, 2004). The respective tie points of the secondary age model are listed in Table 2.

\subsection{Spectral analysis}

Spectral analysis was performed to test for statistically significant cycles with respect to orbital parameters. For analysis of orbital periodicities, the non-constantly sampled time
Table 2. Palaeomagnetic and biostratigraphic tie points used in the primary age model of Site U1389 based on shipboard data following Hernández-Molina et al. (2013) and Stow et al. (2013). 1: Gradstein et al. (2012); 2: Raffi et al. (2006); 3: Lourens et al. (2004); 4: Grunert et al. (2017).

\begin{tabular}{lr}
\hline Depth (mbsf) & Age (ka) \\
\hline 512 & 1660 \\
542 & 1806 \\
551.25 & 1828 \\
554 & 1851 \\
564 & 1861 \\
570 & 1867 \\
574 & 1875 \\
580 & 1898 \\
592 & 1945 \\
595 & 1965 \\
600 & 1975 \\
615.63 & 2005 \\
623 & 2070 \\
629.1 & 2092 \\
629.75 & 2117.5 \\
631.1 & 2132.5 \\
646 & 2425 \\
648.75 & 2435.5 \\
665.1 & 2462.5 \\
666.3 & 2486 \\
673 & 2500 \\
677.45 & 2517.5 \\
687 & 2539 \\
689 & 2552 \\
691.5 & 2560 \\
693.5 & 2583 \\
699 & 2581 \\
799.75 & 2800 \\
\hline &
\end{tabular}

series were analysed by a multi-taper method using the program REDFIT (Schulz and Mudelsee, 2002). Morlet wavelets assuming a $10 \%$ red noise level were calculated following the methods described in Grinsted et al. (2004), Liu 


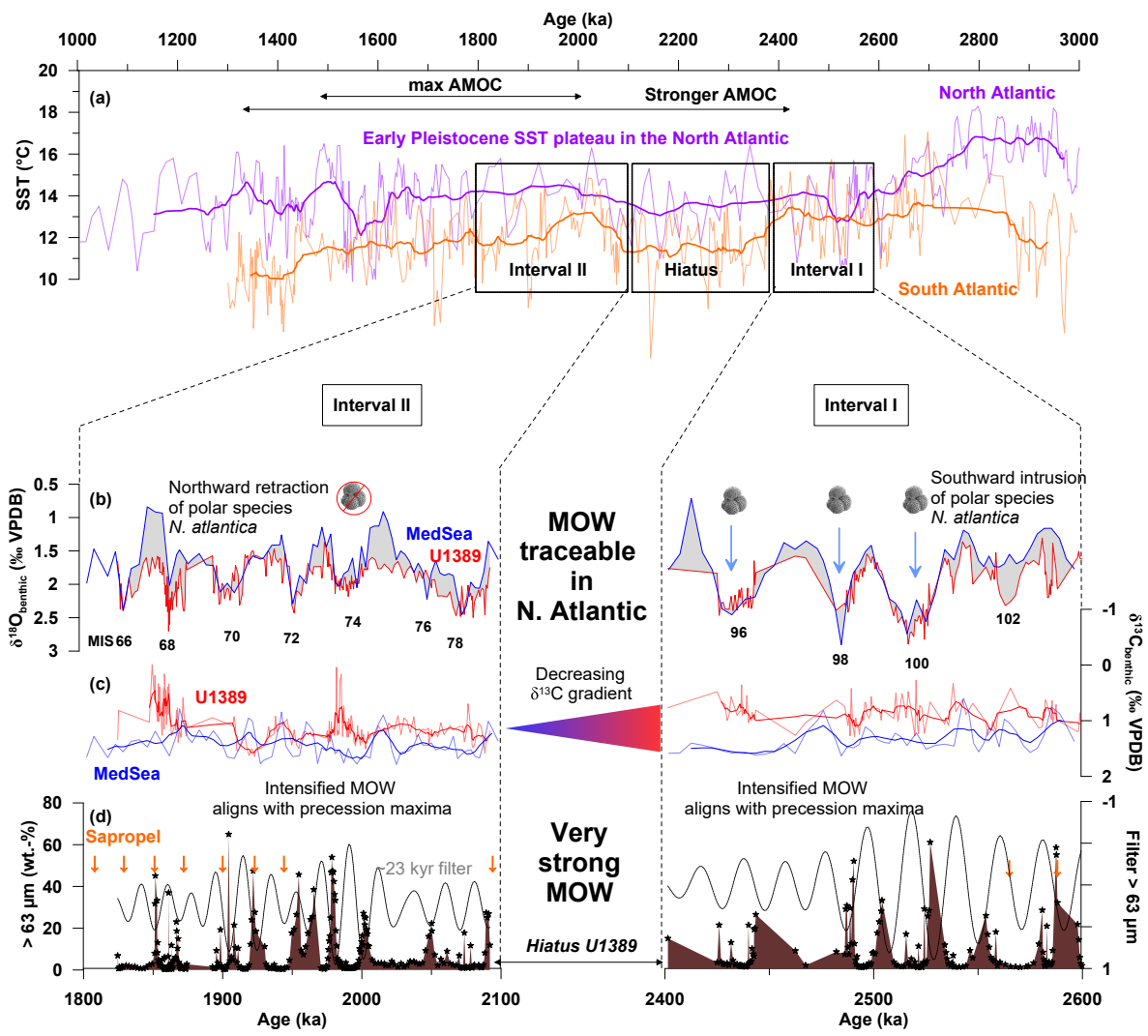

Figure 4. (a) $\mathrm{UK}^{37}$-based sea-surface temperature (SST) record of North Atlantic Site ODP 982 (Lawrence et al., 2009) and South Atlantic Site ODP 1090 (Martinez-Garcia et al., 2010). The running mean has a bandwidth of 23. AMOC phases are marked by black arrows and follow the chronology of Bell et al. (2015). (b) Benthic $\delta^{18} \mathrm{O}$ records of both investigated intervals at Site U1389. Interval I comprises the time frame of 2.6 to $2.4 \mathrm{Ma}$ and Interval II 2.1 to $1.8 \mathrm{Ma}$. Isotopic gradient between both records is indicated by the grey-shaded area. (c) Comparison of $\delta^{13} \mathrm{C}$ of $P$. ariminensis for both investigated intervals at Site U1389 and $\delta^{13} \mathrm{C}$ of the MedSea stack (Lourens et al., 1996a, unpublished data). The running means have a bandwidth of 5. The $C$. ungerianus-based $\delta^{13} \mathrm{C}$ values of the MedSea stack were adjusted to $P$. ariminensis $\delta^{13} \mathrm{C}$ values of Site $\mathrm{U} 1389$ following the interspecies correction presented in this study (d) Grain-size $(63-150 \mu \mathrm{m}$ wt. \%) records for both investigated intervals at Site U1389. The filtered $\sim 23 \mathrm{kyr}$ signal $(f=0.05 \pm 0.01)$ of the grain-size signal is indicated by the black dotted line. Sapropel mid-points are marked by orange arrows and follow the chronology of Emeis et al. (2000).

et al. (2007) and Torrence and Compo (1998) by applying the "biwavelet" R package (Gouhier et al., 2016; R Core Team, 2014).

\section{Results}

\subsection{Age model and sedimentation rates}

The two studied intervals of the Site U1389 $\delta^{18} \mathrm{O}$ record exhibit similar glacial-interglacial variability as present in MedSea stack throughout the Early Pleistocene. The estimated mean sedimentation rate for both intervals is $\sim 0.30 \mathrm{~m} \mathrm{kyr}^{-1}$, which is similar to the sedimentation rate of $\sim 0.25$ to $\sim 0.30 \mathrm{~m} \mathrm{kyr}^{-1}$ that has been calculated from shipboard stratigraphy for the past 3.2 Myr (Hernández-Molina et al., 2013; Stow et al., 2013). A doubling or tripling of the sedimentation rate coincides with the transition of MIS 103 to MIS 102, MIS 101 to MIS 100, and interglacials MIS
99 and MIS 97 in Interval I, as well as MIS 68 in Interval II. Condensed sections with low sedimentation rates of $\sim 0.1 \mathrm{~m} \mathrm{kyr}^{-1}$ correlate with the transition from MIS 98 to MIS 97 and MIS 95 in Interval I and MIS 78 to MIS 75 in Interval II, respectively. Generally, the high-amplitude changes of the sedimentation rate at Site U1389 during the Early Pleistocene are mimicked by a similar behaviour recorded during the Late Pleistocene (Bahr et al., 2015).

\subsection{Stable oxygen and carbon isotopes}

The comparison between both intervals of the $\delta^{18} \mathrm{O}$ record at Site U1389 with the benthic $\delta^{18} \mathrm{O}$ MedSea stack is shown in Fig. 4. In Interval I, lowest values of 1.17 and $1.22 \%$ coincide with interglacials MIS 103 and 101, and the strongest glacial enrichment in $\delta^{18} \mathrm{O}(2.69 \%)$ coincides with MIS 100. Transitional depletion is on average $0.97 \%$ o with highest values $(1.29 \%$ ) in the interval between MIS 101 and 100 (see 
Fig. 4). In Interval II, the lowest values coincide with MIS $73\left(1.36 \%\right.$ ) , whereas the strongest glacial $\delta^{18} \mathrm{O}$ enrichment can be observed during MIS 78, 72 and 68 with 2.47, 2.42 and $2.69 \%$, respectively (see Fig. 4). Transitional depletion is on average $0.82 \%$ with highest values (1.06 and $1.19 \%$ ) in the interval between MIS 73 and 72, and the transition from MIS 69 to MIS 68. Pronounced amplitude offsets between the $\delta^{18} \mathrm{O}$ signal of Site U1389 and MedSea are visible in both intervals but especially during MIS 103, 102, 77, 75 and 67 (Fig. 4). These perturbations are of the order of up to $\sim 0.5 \%$ o (e.g. MIS 75). The comparison between both intervals of the $\delta^{13} \mathrm{C}$ record at Site U1389 with the $\delta^{13} \mathrm{C}$ MedSea stack is shown in Fig. 4. During Interval I, lowest values of 0.27 and $0.32 \%$ coincide with MIS 101 and 100, and the highest values $(\sim 1.27 \%$ o) coincide with the transition of MIS 102 to MIS 101, MIS 100, and the transition between MIS 99 and MIS 98. In Interval II, the lowest values correspond to MIS $74(-0.02 \%)$ and the transition between MIS 68 and $67\left(-0.06 \%\right.$ ). The highest $\delta^{13} \mathrm{C}$ values coincide with MIS $71(1.56 \%$ ).

\subsection{Grain size}

The mean grain-size values $(63-150 \mu \mathrm{m})$ for both investigated intervals are $\sim 8.0 \mathrm{wt}$. \% Highest values of both investigated intervals of up to $\sim 60 \mathrm{wt} . \%$ are correlated with MIS 100 and 77 (Fig. 4). The grain-size variability is seemingly not related to glacial-interglacial variability as a clear response of the grain size to the variability of $\delta^{18} \mathrm{O}$ records at Site U1389 cannot be observed.

\subsection{Spectral analyses}

The grain-size records of Interval I and II at Site U1389 exhibit significance (80 to $90 \%$ ) variance in the precession ( $\sim 23 \mathrm{kyr})$, semi-precession $(\sim 11 \mathrm{kyr})$ and potentially $1 / 3$ precession ( $\sim 7 \mathrm{kyr}$; only significant in Interval II) frequency band (Fig. 5a and b). The obliquity signal is insignificant in both investigated intervals. The wavelet analysis for Interval I (Fig. 5c) reveals that the precession and semi-precession signal is most dominant between 2.55 and $2.50 \mathrm{Myr}$. The lack of stability in the precession band from 2.5 to $2.4 \mathrm{Ma}$ correlates with the reduced sample resolution due to poor core recovery (see Fig. 3). During Interval II the precession and semi-precession signal is most dominant during the interval between 2.0 and 1.9 Ma. Starting from 2.0 Ma, the 1/3precession signal is becoming increasingly more prominent and stable (Fig. 5d).

\section{Discussion}

\subsection{Glacial-interglacial MOW variability at Site U1389 during the Early Pleistocene}

In order to utilize the $\delta^{18} \mathrm{O}$ signal at Site U1389 to trace MOW variability we assume that the global ice volume contributions of the $\delta^{18} \mathrm{O}$ signal within the same time interval for Site U1389 and the Mediterranean Sea are equal. Consequently, differences in $\delta^{18} \mathrm{O}$ are caused by temperature and/or salinity differences of the water masses between both sites. The modern heavy oxygen isotope signal of MOW (see Fig. 1d) is a consequence of its increased temperature and salinity linked to its Mediterranean source region and hence setting it apart from the isotopic lighter overflowing water masses of North Atlantic origin. Therefore, we argue that the similarities of the $\delta^{18} \mathrm{O}$ values between Site U1389 and the MedSea stack during Interval I (2.6-2.4 Ma) and Interval II (2.1-1.8 Ma) emphasize the direct influence of MOW at Site U1389. In this sense, our findings also strongly suggest that MOW formation during the Early Pleistocene was similar to modern conditions, where MOW originates largely from intermediate water masses such as the Levantine Intermediate Water (Millot, 2009, 2014; Millot et al., 2006). The $\delta^{18} \mathrm{O}$ difference between Site U1389 and the Mediterranean Sea is small during glacial periods in both investigated intervals, suggesting that Site U1389 bathed in MOW during these colder climatic conditions throughout the Early Pleistocene time interval (Fig. 4a). This is particularly interesting in light of the proposed vertical shift of the MOW flow path during glacial periods of the Late Pleistocene fostered by the increased density of the outflowing Mediterranean water masses (Kaboth et al., 2016; Lofi et al., 2015; Rogerson et al., 2005; Schönfeld and Zahn, 2000; Toucanne et al., 2007; Voelker et al., 2006). This suggests that Site U1389 was not subjected to major glacial-interglacial-induced flow path changes during the Early Pleistocene, possibly due to its deeper and relatively proximal location to the Strait of Gibraltar, placing it more into the general flow path of upper MOW. These results confirm the inferences derived from Site U1389 of the Late Pleistocene interval, where MOW activity was also shown to be largely unaffected by glacialinterglacial variability but instead predominately influenced by insolation-driven hydro-climatic changes of its Mediterranean source region (Bahr et al., 2015).

In contrast, the interglacial periods of both intervals show a small but relative depletion in the Mediterranean Sea compared to the $\delta^{18} \mathrm{O}$ signal at Site U1389, which might reflect relatively higher temperatures or lower salinity of the intermediate Mediterranean Sea waters with respect to the MOWs during interglacial periods. The strongest intervals of relative $\delta^{18} \mathrm{O}$ depletion throughout both investigated time periods correlate with MIS 103, 102, 75 and 67 characterized by a depletion of up to $\sim 0.5 \%$ in the Mediterranean Sea compared to Site U1389. This shift might correspond to a freshening 

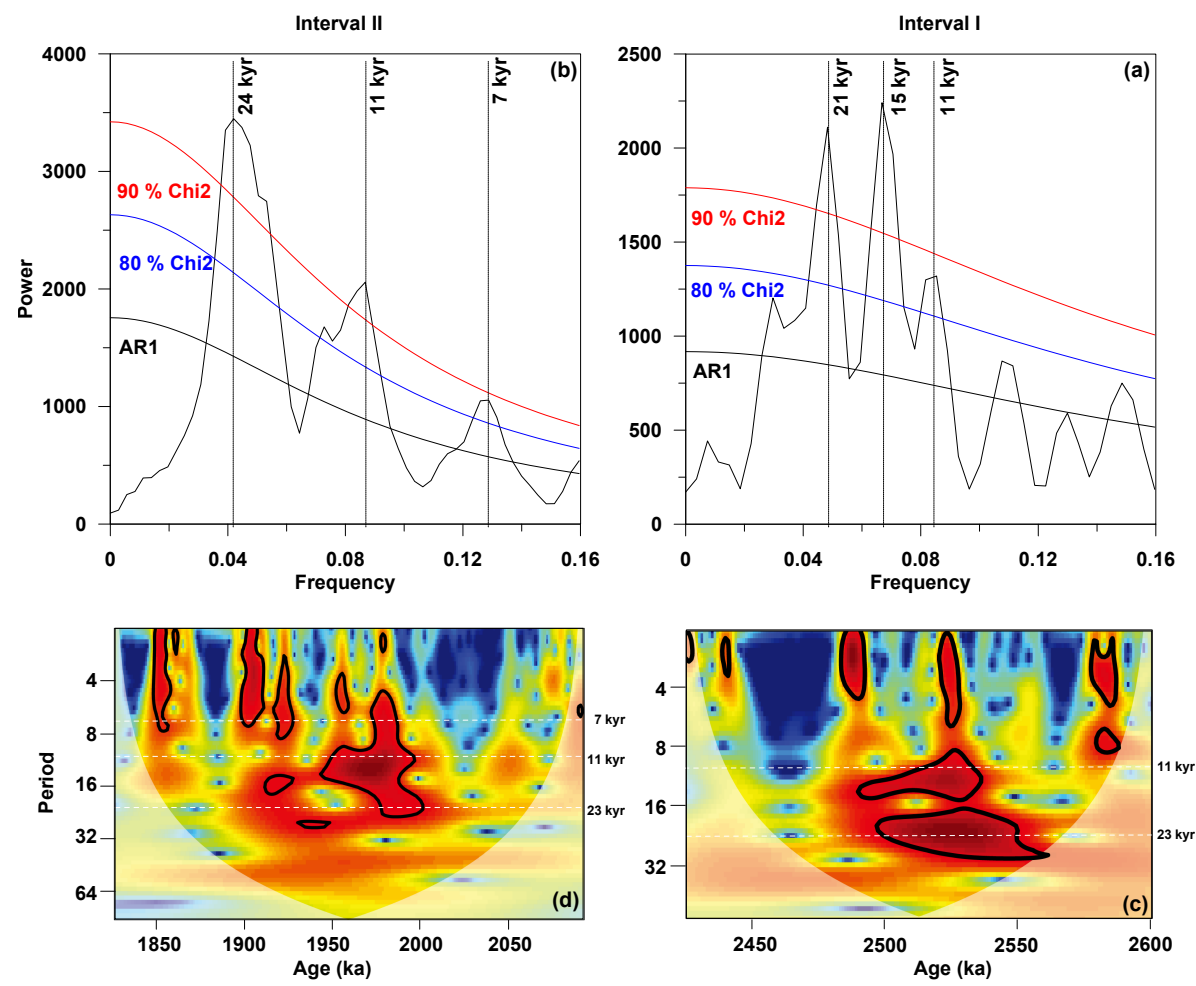

Figure 5. REDFIT power spectra of the grain-size values (63-150 $\mu \mathrm{m}$ fraction in wt. \%) for both investigated intervals of Site U1389: (a) Interval I: 2.6-2.4 Ma; (b) Interval II: 2.1-1.8 Ma. The $90 \%$ (red), $80 \%$ (blue) and AR1 red noise (black) confidence levels are given. (c) Wavelet analysis of the grain-size values $(63-150 \mu \mathrm{m}$ fraction in wt. \%) during Interval I and (d) wavelet analysis of the grain-size values (63-150 $\mu \mathrm{m}$ fraction in wt. \%) during Interval II. Cone of confidence (white) for both intervals is marked. Areas with $>95 \%$ significance level are marked by black lines. Periods corresponding to (semi-, 1/3) precession are marked with dashed white lines.

of the Mediterranean Sea intermediate water column during sapropel formation and a consequently reduction of MOW influence at Site U1389 (Rogerson et al., 2012). In the case of MIS 102 and 67, sapropels have been documented in the eastern Mediterranean Sea basin but not for MIS 75 (Emeis et al., 2000; Lourens, 2004; Lourens et al., 1992, 1996a). During Interval II, the generally higher $\delta^{13} \mathrm{C}$ values at U1389 are close to those of the Mediterranean Sea values, implying that MOW was in fact the predominant source of bottom water at Site U1389 between 1.8 and $2.1 \mathrm{Ma}$ (Fig. 4c). In contrast, the older Interval I is characterized by a slightly increased ${ }^{13} \mathrm{C}$ gradient between Site U1389 and the Mediterranean Sea, suggesting a generally larger contribution of ambient North Atlantic water masses carrying a lower $\delta^{13} \mathrm{C}$ signal to the site. This could indicate a more vigorous MOW or that the MOW flow core during Interval I was less proximal than during Interval II. The later argument seems to be supported by the grain size and its variability, as Interval II shows a $\sim 10 \%$ decrease in mean and amplitude relative to Interval I (Fig. 4d). This would suggest that, during Interval I, Site U1389 was less proximal to the flow core, albeit more sensitive to flow strength changes, whereas during Interval II the MOW plume settled upon Site U1389. This is further supported by findings from seismic records in the Gulf of Cadiz that also suggest that the present-day circulation established at $\sim 2.1 \mathrm{Ma}$ (Hernandez-Molina et al., 2014b).

A distinct increase in the $\delta^{13} \mathrm{C}$ gradient can be seen during MIS 96, which may document a particularly strong MOW activity. However, the sample resolution during MIS 96 and the subsequent MIS 95 is relatively low, so that the increase in the $\delta^{13} \mathrm{C}$ gradient remains ambiguous. The onset of the subsequent hiatus, which has been argued to represent depositional erosion due to increased bottom current activity of the MOW, could be an argument for a strong intensification of MOW activity (Hernandez-Molina et al., 2014b).

\subsection{Precession control on MOW strength during the Early Pleistocene: similarities to Late Pleistocene MOW behaviour?}

Untreated grain-size weight percentages can only give an indication for patterns in flow strength (Kaboth et al., 2016, 2017). For the two investigated intervals we find that the $63-150 \mu \mathrm{m}$ fraction variability is seemingly modulated by a $\sim 23 \mathrm{kyr}$ pacing (Fig. 4d). This relationship is evident in the power spectrum of the grain-size data, which yields for both intervals a dominance in the precession and semi-precession frequency band ( $\sim 23$ and $\sim 11 \mathrm{kyr}$ ) (Fig. 5a and b). The 
dominance and stability of the recorded precessional and semi-precessional signal in the grain-size variability throughout both investigated intervals is also highlighted by the wavelet analysis (Fig. 5c and d). This suggests that the flow strength of MOW was probably directly modulated by precession during the Early Pleistocene, aligning with previous findings based on $\mathrm{Zr}$ / Al ratios at Site U1389 from the Late Pleistocene (Bahr et al., 2015). In fact, a strong processional influence was also shown for $\delta^{18} \mathrm{O}$ records from the eastern Mediterranean Sea (ODP site 967 and 969) and the midlatitude North Atlantic during MIS 100 to MIS 96 (Becker et al., 2005, 2006). For the Late Pleistocene, an inverse relationship was found between precession and MOW dynamics (Bahr et al., 2015; Kaboth et al., 2016). During periods of increased summer insolation at the time of precession minima, the monsoonal rain belts expand northward, causing an increase in freshwater discharge by the river Nile (e.g. Rohling et al., 2015; Rossignol-Strick, 1983, 1985). This effectively impedes intermediate water mass formation in the eastern Mediterranean, thereby suppressing MOW production. From the correlation of the filtered $\sim 23 \mathrm{kyr}$ signal to the grainsize variability at site U1389, a similar relationship already existed during both investigated intervals of the Early Pleistocene (Fig. 4d). We also find significant semi-precession ( $\sim 11 \mathrm{kyr})$ influence indicative for a primarily low-latitude response argued to originate in the tropics (Rutherford and D'Hondt, 2000; de Winter et al., 2014).

The $\delta^{18} \mathrm{O}$ signal comparison of Site U1389 and the MedSea stack is also particular interesting in the context of sapropel formation, as the MedSea stack due to its intermediate palaeo-water depth was sensitive to freshwater-induced changes in the intermediate water composition. A substantial freshening of the intermediate water masses in the Mediterranean Sea can be inferred from the strongly depleted $\delta^{18} \mathrm{O}$ values during MIS 103, 102, 77, 75 and 67 relative to Site U1389 (Fig. 4a). The potentially reduced MOW supply at Site U1389 at the same time would increase the isotopic gradient between both locations, as Site U1389 could be affected by more open-ocean conditions. However, despite the low sample resolution, this does not seem to be a persistent relationship throughout both investigated intervals. For the Holocene S1, the proposed reduction in MOW has been documented by the absence of sandy contourite layers from the middle slope of the Gulf of Cadiz, indicating a sudden reduction in flow strength and sediment delivery by the MOW (Toucanne et al., 2007; Voelker et al., 2006). The grain-size values throughout both investigated intervals at Site U1389 are typically low during sapropel formation, supporting the findings from the middle and upper slope during the Late Pleistocene (Kaboth et al., 2016). However, the grain size is seemingly increased during the sapropels deposited in the eastern Mediterranean Sea at $\sim 1.92$ and 1.85 Myr (Fig. 4d). This in-phase behaviour could potentially be a tuning artefact or relate to the fact that numerical model simulations imply that remnant thermally driven overturning circulation still occurs throughout the most extreme freshening events in the eastern Mediterranean Sea (Myers, 2002). This would imply that MOW during the sapropel formation at $\sim 1.92$ and $1.85 \mathrm{Myr}$ was potentially still active at Site U1389.

\subsection{Did MOW contribute to the Early Pleistocene climate transition?}

Between $\sim 2.8$ and $2.4 \mathrm{Myr}$ (Interval I) occurrences of Neogloboquadrina atlantica (sin.), an extinct polar species, were reported in the Mediterranean Sea during glacial periods, suggesting the intrusion of colder water masses into the Mediterranean Basin (Becker et al., 2005; Lourens and Hilgen, 1997; Zachariasse et al., 1990). We also find $N$. atlantica (sin.) present during glacial periods of Interval I (Fig. 4b), confirming a more southern delineation of transitional and subpolar water masses during glacial periods of the Early Pleistocene than in recent setting (Voelker et al., 2015). This latitudinal shift might have occurred in concert with a more sluggish AMOC at least during the glacial periods, if not throughout the whole time interval (Bell et al., 2015). Colder and more arid background conditions in the Mediterranean Sea could foster a stronger MOW analogous to cold spells related to Heinrich events throughout the last climatic cycle (Bahr et al., 2014, 2015; Kaboth et al., 2016). An intensification of MOW during Interval I would align with the increased $\delta^{13} \mathrm{C}$ gradient between Site U1389 and the Mediterranean Sea, suggesting a more vigorous MOW, which is also reflected by higher grain-size amplitudes compared to Interval II (Fig. 4c and d). Our data, however, do not extend further back in time to test whether these conditions coincide with the proposed steady increase in MOW activity in the Gulf of Cadiz since 3.2 Ma as inferred from natural gamma ray logs and seismic profiles (Hernández-Molina et al., 2015), and with the arrival of Mediterranean-sourced intermediate water mass at North Atlantic sites DSDP 548 and 552 and ODP 982 from $~ 3.6$ Ma onwards (Khélifi et al., 2014; Loubere, 1987). This northward protrusion of warm and saline MOW towards high-latitude deep-water convection hotspots is considered an important modulator of the North Atlantic salt budget (Bahr et al., 2015; Rogerson et al., 2006; Voelker et al., 2006). We suggest that steady contributions of MOW throughout Interval I continuously supplied salt into the North Atlantic and potentially preconditioned the strong AMOC activity phase starting at $\sim 2.4 \mathrm{Ma}$ (Bell et al., 2015), when a tipping point was reached (Fig. 4a). In this regard, Khélifi and Frank (2014) and Lisiecki (2014) suggested the lack of increased overturning circulation in the deep water during this time interval. At a first glance this stands in contrast to the proposed increased overturning circulation postulated by Bell et al. (2015) in relation to changes in the North Atlantic surface water mass trajectory. We argue that the changes in the surface water masses potentially relate to an intensification in the intermediate not the deep-water branch of the overturning cell stimulated by 
the increased northward protrusion of MOW. Such a scenario has already been highlighted in Bahr et al. (2015) for MIS 5 and Late Pleistocene climatic conditions. Hence, the Early Pleistocene MOW might have acted as a positive climatic feedback mechanism against the background of increasingly colder temperatures. This contrasts with the warm Pliocene setting where it was proposed that MOW contributions to the North Atlantic did not have a significant influence on the AMOC (Khélifi et al., 2014).

The intensification of the AMOC is also in concert with the disappearance of $N$. atlantica (sin.) in the Mediterranean Sea and the North Atlantic up to at least $52^{\circ} \mathrm{N}$ after $\sim 2.4 \mathrm{Ma}$ (Lourens and Hilgen, 1997; Weaver and Clement, 1987). This suggests the reduction in southward protrusion of colder water masses and hence the $N$. atlantica (sin.) extinction, as well as a return to a warmer background climate in the Mediterranean region during glacial periods (Lourens, 2008).

The increased AMOC activity is documented by the North Atlantic SST record of Site ODP 982 displaying a plateau starting at $\sim 2.4 \mathrm{Ma}$, indicating more steady climate conditions (Fig. 4a) and a stagnation in Northern Hemisphere ice sheet growth (Bell et al., 2015; Lawrence et al., 2009). Coinciding with this stabilization of North Atlantic SSTs is a cooling in the South Atlantic attributed to a northward piracy of the tropical warmer water pool by a strong AMOC and implying an active interhemispheric climatic seesaw at that time (Fig. 4a, Etourneau et al., 2010; Patterson et al., 2014). Despite the lack of direct data at Site U1389 between the 2.4 and 2.1 Ma interval, seismic records from the Gulf of Cadiz suggest that the hiatus represents a depositional erosion feature caused by intensified bottom current activity and hence strong MOW flow (Hernandez-Molina et al., 2014b). This would align with the continuous strong AMOC activity in the North Atlantic (Bell et al., 2015).

From the reduction of the $\delta^{18} \mathrm{O}$ and $\delta^{13} \mathrm{C}$ gradient between Site U1389 and the MedSea stack (Fig. 4), it appears that after $\sim 2.1 \mathrm{Ma}$ MOW settled upon Site U1389 (Fig. 4). The reduction in grain size might also imply more stable MOW behaviour, whereas MOW during the transitional phase of the older Interval I was probably more erratic, indicated by the high grain-size variability and the increased $\delta^{13} \mathrm{C}$ gradient (Fig. 4c and d). Unfortunately, we lack data beyond $\sim 2.5 \mathrm{Ma}$ from ODP sites 549,552 and 982 to further trace the temporal MOW influence in the high-latitude North Atlantic throughout Interval II, but it stands to reason that continued MOW contributions also during Interval II might have contributed to the sustained AMOC activity.

\section{Conclusions}

Based on our results, the supply of MOW to Site U1389 was already established during the Early Pleistocene and not limited to Late and Middle Pleistocene climate conditions. In addition, we find indication that the MOW flow strength might have been modulated by precession superimposed on glacial-interglacial change. This aligns with findings from the Late Pleistocene at Site U1389 and suggests that Site U1389 is also a true recorder of MOW variability throughout the Early Pleistocene. In the broader view of the Early Pleistocene climate evolution we find an indication that increased MOW might have contributed to the increased AMOC phases starting from $2.4 \mathrm{Ma}$ and thus influencing North Atlantic oceanic heat transport.

Data availability. The data related to this paper are publicly available via https://doi.org/10.1594/PANGAEA.871499 (Kaboth et al., 2017b).

Competing interests. The authors declare that they have no conflict of interest.

Acknowledgements. Firstly, we would like to thank the two anonymous reviewers for their careful handling of the manuscript as well as for their constructive comments and suggestions that helped in improving our manuscript. We acknowledge the Integrated Ocean Drilling Program (IODP) for providing the samples used in this study as well as Arnold van Dijk at Utrecht University for analytical support. This research was funded by a NWO-ALW grant (project number 865.10.001) to Lucas J. Lourens and contributions from project P25831-N29 of the Austrian Science Fund (FWF).

Edited by: Arne Winguth

Reviewed by: two anonymous referees

\section{References}

Ambar, I. and Howe, M. R.: Observations of the mediterranean outflow - II the deep circulation in the vicinity of the gulf of cadiz, Deep Sea Res. Part A, 26, 555-568, https://doi.org/10.1016/0198-0149(79)90096-7, 1979.

Bahr, A., Jiménez-Espejo, F. J., Kolasinac, N., Grunert, P., Hernández-Molina, F. J., Röhl, U., Voelker, A. H. L., Escutia, C., Stow, D. A. V., Hodell, D., and Alvarez-Zarikian, C. A.: Deciphering bottom current velocity and paleoclimate signals from contourite deposits in the Gulf of Cadiz during the last 140kyr: an inorganic geochemical approach, Geochemistry, Geophys. Geosystems, 15, 3145-3160, https://doi.org/10.1002/2014GC005356, 2014.

Bahr, A., Kaboth, S., Jiménez-Espejo, F. J., Sierro, F. J., Voelker, A. H. L., Lourens, L., Röhl, U., Reichart, G. J., Escutia, C., Hernández-Molina, F. J., Pross, J., and Friedrich, O.: Persistent monsoonal forcing of Mediterranean Outflow Water dynamics during the late Pleistocene, Geology, 43, 951-954, https://doi.org/10.1130/G37013.1, 2015.

Baringer, M. O. and Price, J. F.: Mixing and Spreading of the Mediterranean Outflow, J. Phys. 
Oceanogr., 27, 1654-1677, https://doi.org/10.1175/15200485(1997)027<1654:MASOTM>2.0.CO;2, 1997.

Becker, J., Lourens, L. J., Hilgen, F. J., van derLaan, E., Kouwenhoven, T. J., and Reichart, G.-J.: Late Pliocene climate variability on Milankovitch to millennial time scales: A high-resolution study of MIS100 from the Mediterranean, Palaeogeogr. Palaeoclimatol. Palaeoecol., 228, 338-360, https://doi.org/10.1016/j.palaeo.2005.06.020, 2005.

Becker, J., Lourens, L. J., and Raymo, M. E.: High-frequency climate linkages between the North Atlantic and the Mediterranean during marine oxygen isotope stage 100 (MIS100), Paleoceanography, 21, PA3002, https://doi.org/10.1029/2005PA001168, 2006

Bell, D. B., Jung, S. J. A., and Kroon, D.: The Plio-Pleistocene development of Atlantic deep-water circulation and its influence on climate trends, Quat. Sci. Rev., 123, 265-282, https://doi.org/10.1016/j.quascirev.2015.06.026, 2015.

Borenäs, K. M., Wåhlin, A. K., Ambar, I., and Serra, N.: The Mediterranean outflow splitting - a comparison between theoretical models and CANIGO data, Deep Sea Res. Part II, 49, 41954205, https://doi.org/10.1016/S0967-0645(02)00150-9, 2002.

Bryden, H. L. and Stommel, H. M.: Liminting processes thatdetermine basic features of the circulation in the Mediterranean Sea, Oceanol. Acta, 7, 289-296, 1984.

Bryden, H. L., Candela, J., and Kinder, T. H.: Exchange through the Strait of Gibraltar, Prog. Oceanogr., 33, 201-248, https://doi.org/10.1016/0079-6611(94)90028-0, 1994.

Cramp, A. and O'Sullivan, G.: Neogene sapropels in the Mediterranean: a review, Mar. Geol., 153, 11-28, https://doi.org/10.1016/S0025-3227(98)00092-9, 1999.

de Winter, N. J., Zeeden, C., and Hilgen, F. J.: Low-latitude climate variability in the Heinrich frequency band of the Late Cretaceous greenhouse world, Clim. Past, 10, 1001-1015, https://doi.org/10.5194/cp-10-1001-2014, 2014.

Emeis, K.-C., Sakamoto, T., Wehausen, R., and Brumsack, H.-J.: The sapropel record of the eastern Mediterranean Sea - results of Ocean Drilling Program Leg 160, Palaeogeogr. Palaeoclimatol. Palaeoecol., 158, 371-395, https://doi.org/10.1016/S00310182(00)00059-6, 2000.

Etourneau, J., Schneider, R., Blanz, T., and Martinez, P.: Intensification of the Walker and Hadley atmospheric circulations during the Pliocene-Pleistocene climate transition, Earth Planet. Sci. Lett., 297, 103-110, https://doi.org/10.1016/j.eps1.2010.06.010, 2010.

Fiúza, A. F. G., Hamann, M., Ambar, I., Díaz del Río, G., González, N., and Cabanas, J. M.: Water masses and their circulation off western Iberia during May 1993, Deep Sea Res. Part I, 45, 11271160, https://doi.org/10.1016/S0967-0637(98)00008-9, 1998.

Fontanier, C., Mackensen, A., Jorissen, F. J., Anschutz, P., Licari, L., and Griveaud, C.: Stable oxygen and carbon isotopes of live benthic foraminifera from the Bay of Biscay: Microhabitat impact and seasonal variability, Mar. Micropaleontol., 58, 159-183, https://doi.org/10.1016/j.marmicro.2005.09.004, 2006.

García-Gallardo, Á., Grunert, P., Van derSchee, M., Sierro, F. J., Jiménez-Espejo, F. J., Alvarez Zarikian, C. A., and Piller, W. E.: Benthic foraminifera-based reconstruction of the first Mediterranean-Atlantic exchange in the early Pliocene Gulf of Cadiz, Palaeogeogr. Palaeoclimatol. Palaeoecol., 472, 93-107, https://doi.org/10.1016/j.palaeo.2017.02.009, 2017.
Gouhier, T. C., Grinstead, A., and Simko, V.: biwavelet: Conduct univariate and bivariate wavelet analyses (Version 0.20.10), available at: http://github.com/tgouhier/biwavelet (last access: July 2017), 2016.

Gradstein, F. M., Ogg, J. G., and Hilgen, F. J.: On The Geologic Time Scale, Newsletters Stratigr., 45, 171-188, https://doi.org/10.1127/0078-0421/2012/0020, 2012.

Grinsted, A., Moore, J. C., and Jevrejeva, S.: Application of the cross wavelet transform and wavelet coherence to geophysical time series, Nonlin. Processes Geophys., 11, 561-566, https://doi.org/10.5194/npg-11-561-2004, 2004.

Grunert, P., Balestra, B., Richter, C., Flores, J.-A., Auer, G., Garcia Gallardo, A., and Piller, W. E.: Revised and refined age model for the upper Pliocene of IODP Site U1389 (IODP Exp. 339, Gulf of Cadiz), Newsl. Stratigr., https://doi.org/10.1127/nos/2017/0396, 2017.

Hernández-Molina, F. J., Llave, E., Stow, D. A. V., García, M., Somoza, L., Vázquez, J. T., Lobo, F. J., Maestro, A., Díaz del Río, V., León, R., Medialdea, T., and Gardner, J.: The contourite depositional system of the Gulf of Cádiz: A sedimentary model related to the bottom current activity of the Mediterranean outflow water and its interaction with the continental margin, Deep Sea Res. Part II, 53, 1420-1463, https://doi.org/10.1016/j.dsr2.2006.04.016, 2006.

Hernández-Molina, F. J., Stow, D., Alvarez-Zarikian, C., and Expedition IODP 339 Scientists: IODP Expedition 339 in the Gulf of Cadiz and off West Iberia: decoding the environmental significance of the Mediterranean outflow water and its global influence, Sci. Dril., 16, 1-11, https://doi.org/10.5194/sd-16-1-2013, 2013.

Hernandez-Molina, F. J., Llave, E., Preu, B., Ercilla, G., Fontan, A., Bruno, M., Serra, N., Gomiz, J. J., Brackenridge, R. E., Sierro, F. J., Stow, D. A.V., Garcia, M., Juan, C., Sandoval, N., and Arnaiz, A.: Contourite processes associated with the Mediterranean Outflow Water after its exit from the Strait of Gibraltar: Global and conceptual implications, Geology, 42, 227-230, https://doi.org/10.1130/G35083.1, 2014a.

Hernandez-Molina, F. J., Stow, D. A. V., Alvarez-Zarikian, C. A., Acton, G., Bahr, A., Balestra, B., Ducassou, E., Flood, R., Flores, J.-A., Furota, S., Grunert, P., Hodell, D., JimenezEspejo, F., Kim, J. K., Krissek, L., Kuroda, J., Li, B., Llave, E., Lofi, J., Lourens, L., Miller, M., Nanayama, F., Nishida, N., Richter, C., Roque, C., Pereira, H., Sanchez Goni, M. F., Sierro, F. J., Singh, A. D., Sloss, C., Takashimizu, Y., Tzanova, A., Voelker, A., Williams, T., and Xuan, C.: Onset of Mediterranean outflow into the North Atlantic, Science, 344, 1244-1250, https://doi.org/10.1126/science.1251306, 2014b.

Hernández-Molina, F. J., Sierro, F. J., Llave, E., Roque, C., Stow, D. A.V, Williams, T., Lofi, J., Van derSchee, M., Arnaiz, A., Ledesma, S., Rosales, C., Rodriguez-Tovar, F. J., PardoIguzquiza, E., and Brackenridge, R. E.: Evolution of the Gulf of Cadiz margin and southwest Portugal contourite depositional system: Tectonic, sedimentary and paleoceanographic implications from IODP expedition 339, Mar. Geol., 377, 7-39, https://doi.org/10.1016/j.margeo.2015.09.013, 2015.

Kaboth, S., Bahr, A., Reichart, G.-J., Jacobs, B., and Lourens, L. J.: New insights into upper MOW variability over the last $150 \mathrm{kyr}$ from IODP 339 Site U1386 in the Gulf of Cadiz, Mar. Geol., 377 , 136-145, https://doi.org/10.1016/j.margeo.2015.08.014, 2016. 
Kaboth, S., de Boer, B., Bahr, A., Zeeden, C., and Lourens, L. J.: Mediterranean Outflow Water dynamics during the past $\sim 570$ kyr: Regional and Global implications: Midto Late Pleistocene MOW, Paleoceanography, 32, 634-647, https://doi.org/10.1002/2016PA003063, 2017a.

Kaboth, S., Grunert, P., and Lourens, L. J.: Data set of "Mediterranean Outflow Water variability during the Early Pleistocene", available at: https://doi.org/10.1594/PANGAEA.871499, 2017b.

Khélifi, N. and Frank, M.: A major change in North Atlantic deep water circulation 1.6 million years ago, Clim. Past, 10, 14411451, https://doi.org/10.5194/cp-10-1441-2014, 2014.

Khelifi, N., Sarnthein, M., Andersen, N., Blanz, T., Frank, M., Garbe-Schonberg, D., Haley, B. A., Stumpf, R., and Weinelt, M.: A major and long-term Pliocene intensification of the Mediterranean outflow, 3.5-3.3 Ma ago, Geology, 37, 811-814, https://doi.org/10.1130/G30058A.1, 2009.

Khélifi, N., Sarnthein, M., Frank, M., Andersen, N., and Garbe-Schönberg, D.: Late Pliocene variations of the Mediterranean outflow, Mar. Geol., 357, 182-194, https://doi.org/10.1016/j.margeo.2014.07.006, 2014.

Lawrence, K. T., Herbert, T. D., Brown, C. M., Raymo, M. E., and Haywood, A. M.: High-amplitude variations in North Atlantic sea surface temperature during the early Pliocene warm period, Paleoceanography, 24, PA2218, https://doi.org/10.1029/2008PA001669, 2009.

Lisiecki, L. E.: Atlantic overturning responses to obliquity and precession over the last $3 \mathrm{Myr}$, Paleoceanography, 29, 71-86, https://doi.org/10.1002/2013PA002505, 2014.

Liu, Y., San Liang, X., and Weisberg, R. H.: Rectification of the Bias in the Wavelet Power Spectrum, J. Atmos. Ocean. Technol., 24, 2093-2102, https://doi.org/10.1175/2007JTECHO511.1, 2007.

Llave, E., Schönfeld, J., Hernández-Molina, F. J., Mulder, T., Somoza, L., Díaz Del Río, V., and Sánchez-Almazo, I.: Highresolution stratigraphy of the Mediterranean outflow contourite system in the Gulf of Cadiz during the late Pleistocene: The impact of Heinrich events, Mar. Geol., 227, 241-262, https://doi.org/10.1016/j.margeo.2005.11.015, 2006.

Lofi, J., Voelker, A. H. L., Ducassou, E., Hernández-Molina, F. J., Sierro, F. J., Bahr, A., Galvani, A., Lourens, L. J., PardoIgúzquiza, E., Pezard, P., Rodríguez-Tovar, F. J., and Williams, T.: Quaternary chronostratigraphic framework and sedimentary processes for the Gulf of Cadiz and Portuguese Contourite Depositional Systems derived from Natural Gamma Ray records, Mar. Geol., https://doi.org/10.1016/j.margeo.2015.12.005, 2015.

Loubere, P.: Changes in mid-depth North Atlantic and Mediterranean circulation during the Late Pliocene - Isotopic and sedimentological evidence, Mar. Geol., 77, 15-38, https://doi.org/10.1016/0025-3227(87)90081-8, 1987.

Lourens, L. J.: Revised tuning of Ocean Drilling Program Site 964 and KC01B (Mediterranean) and implications for the $\delta 18 \mathrm{O}$, tephra, calcareous nannofossil, and geomagnetic reversal chronologies of the past 1.1 Myr, Paleoceanography, 19, PA3010, https://doi.org/10.1029/2003PA000997, 2004.

Lourens, L. J.: On the Neogene-Quaternary debate, Episodes, 31, 239-242, 2008.

Lourens, L. J. and Hilgen, F. J.: Long-periodic variations in the earth's obliquity and their relation to third-order eustatic cycles and late Neogene glaciations, Quat. Int., 40, 43-52, https://doi.org/10.1016/S1040-6182(96)00060-2, 1997.
Lourens, L. J., Hilgen, F. J., Gudjonsson, L., and Zachariasse, W. J.: Late Pliocene to early Pleistocene astronomically forced sea surface productivity and temperature variations in the Mediterranean, Mar. Micropaleontol., 19, 49-78, https://doi.org/10.1016/0377-8398(92)90021-B, 1992.

Lourens, L. J., Hilgen, F. J., Raffi, I., and Vergnaud-Grazzini, C.: Early Pleistocene chronology of the Vrica Section (Calabria, Italy), Paleoceanography, 11, 797-812, https://doi.org/10.1029/96PA02691, 1996a.

Lourens, L. J., Antonarakou, A., Hilgen, F. J., VanHoof, A. A. M., Vergnaud-Grazzini, C., and Zachariasse, W. J.: Evaluation of the Plio-Pleistocene astronomical timescale, Paleoceanography, 11, 391-413, https://doi.org/10.1029/96PA01125, 1996 b.

Marchitto, T. M., Curry, W. B., Lynch-Stieglitz, J., Bryan, S. P., Cobb, K. M., and Lund, D. C.: Improved oxygen isotope temperature calibrations for cosmopolitan benthic foraminifera, Geochim. Cosmochim. Acta, 130, 1-11, https://doi.org/10.1016/j.gca.2013.12.034, 2014.

Martinez-Garcia, A., Rosell-Mele, A., McClymont, E. L., Gersonde, R., and Haug, G. H.: Subpolar Link to the Emergence of the Modern Equatorial Pacific Cold Tongue, Science, 328, 15501553, https://doi.org/10.1126/science.1184480, 2010.

Millot, C.: Another description of the Mediterranean Sea outflow, Prog. Oceanogr., 82, 101-124, https://doi.org/10.1016/j.pocean.2009.04.016, 2009.

Millot, C.: Heterogeneities of in- and out-flows in the Mediterranean Sea, Prog. Oceanogr., 120, 254-278, https://doi.org/10.1016/j.pocean.2013.09.007, 2014.

Millot, C., Candela, J., Fuda, J.-L., and Tber, Y.: Large warming and salinification of the Mediterranean outflow due to changes in its composition, Deep Sea Res. Part I, 53, 656-666, https://doi.org/10.1016/j.dsr.2005.12.017, 2006.

Mulder, T., Lecroart, P., Hanquiez, V., Marches, E., Gonthier, E., Guedes, J.-C., Thiébot, E., Jaaidi, B., Kenyon, N., Voisset, M., Perez, C., Sayago, M., Fuchey, Y., and Bujan, S.: The western part of the Gulf of Cadiz: contour currents and turbidity currents interactions, Geo-Marine Lett., 26, 31-41, https://doi.org/10.1007/s00367-005-0013-z, 2006.

Myers, P. G.: Flux-forced simulations of the paleocirculation of the Mediterranean, Paleoceanography, 17, 1009, https://doi.org/10.1029/2000PA000613, 2002.

Patterson, M. O., McKay, R., Naish, T., Escutia, C., JimenezEspejo, F. J., Raymo, M. E., Meyers, S. R., Tauxe, L., Brinkhuis, H., Klaus, A., Fehr, A., Bendle, J. A. P., Bijl, P. K., Bohaty, S. M., Carr, S. A., Dunbar, R. B., Flores, J. A., Gonzalez, J. J., Hayden, T. G., Iwai, M., Katsuki, K., Kong, G. S., Nakai, M., Olney, M. P., Passchier, S., Pekar, S. F., Pross, J., Riesselman, C. R., Röhl, U., Sakai, T., Shrivastava, P. K., Stickley, C. E., Sugasaki, S., Tuo, S., van deFlierdt, T., Welsh, K., Williams, T., and Yamane, M.: Orbital forcing of the East Antarctic ice sheet during the Pliocene and Early Pleistocene, Nat. Geosci., 7, 841-847, https://doi.org/10.1038/ngeo2273, 2014.

Peliz, Á., Dubert, J., Santos, A. M. P., Oliveira, P. B., and LeCann, B.: Winter upper ocean circulation in the Western Iberian BasinFronts, Eddies and Poleward Flows: an overview, Deep Sea Res. Part I, 52, 621-646, https://doi.org/10.1016/j.dsr.2004.11.005, 2005.

Peliz, A., Marchesiello, P., Santos, A. M. P., Dubert, J., TelesMachado, A., Marta-Almeida, M., and LeCann, B.: Surface cir- 
culation in the Gulf of Cadiz: 2. Inflow-outflow coupling and the Gulf of Cadiz slope current, J. Geophys. Res., 114, C03011, https://doi.org/10.1029/2008JC004771, 2009.

Raffi, I., Backman, J., Fornaciari, E., Pälike, H., Rio, D., Lourens, L., and Hilgen, F.: A review of calcareous nannofossil astrobiochronology encompassing the past 25 million years?, Quat. Sci. Rev., 25, 3113-3137, https://doi.org/10.1016/j.quascirev.2006.07.007, 2006.

Raymo, M. E., Hodell, D., and Jansen, E.: Response of deep ocean circulation to initiation of northern hemisphere glaciation (3-2 MA), Paleoceanography, 7, 645-672, https://doi.org/10.1029/92PA01609, 1992.

R Core Team: R: A language and environment for statistical computing, available at: http://www.r-project.org/ (last access: July 2017), 2014.

Rogerson, M., Rohling, E. J., Weaver, P. P. E., and Murray, J. W.: Glacial to interglacial changes in the settling depth of the Mediterranean Outflow plume, Paleoceanography, 20, 1-12, https://doi.org/10.1029/2004PA001106, 2005.

Rogerson, M., Rohling, E. J., and Weaver, P. P. E.: Promotion of meridional overturning by Mediterranean-derived salt during the last deglaciation, Paleoceanography, 21, PA4101, https://doi.org/10.1029/2006PA001306, 2006.

Rogerson, M., Schönfeld, J., and Leng, M. J.: Qualitative and quantitative approaches in palaeohydrography: A case study from core-top parameters in the Gulf of Cadiz, Mar. Geol., 280, 150167, https://doi.org/10.1016/j.margeo.2010.12.008, 2011.

Rogerson, M., Rohling, E. J., Bigg, G. R., and Ramirez, J.: Paleoceanography of the Atlantic-Mediterranean exchange: Overview and first quantitative assessment of climatic forcing, Rev. Geophys., 50, RG2003, https://doi.org/10.1029/2011RG000376, 2012.

Rohling, E. J., Marino, G., and Grant, K. M.: Mediterranean climate and oceanography, and the periodic development of anoxic events (sapropels), Earth-Sci. Rev., 143, 62-97, https://doi.org/10.1016/j.earscirev.2015.01.008, 2015.

Rossignol-Strick, M.: African monsoons, an immediate climate response to orbital insolation, Nature, 304, 46-49, https://doi.org/10.1038/304046a0, 1983.

Rossignol-Strick, M.: Mediterranean Quaternary sapropels, an immediate response of the African monsoon to variation of insolation, Palaeogeogr. Palaeoclimatol. Palaeoecol., 49, 237-263, https://doi.org/10.1016/0031-0182(85)90056-2, 1985.

Rutherford, S. and D'Hondt, S.: Early onset and tropical forcing of 100,000-year Pleistocene glacial cycles, Nature, 408, 72-75, https://doi.org/10.1038/35040533, 2000.

Schönfeld, J.: A new benthic foraminiferal proxy for nearbottom current velocities in the Gulf of Cadiz, northeastern Atlantic Ocean, Deep. Res. Part I, 49, 1853-1875, https://doi.org/10.1016/S0967-0637(02)00088-2, 2002.

Schönfeld, J. and Zahn, R.: Late Glacial to Holocene history of the Mediterranean outflow. Evidence from benthic foraminiferal assemblages and stable isotopes at the Portuguese margin, Palaeogeogr. Palaeoclimatol. Palaeoecol., 159, 85-111, https://doi.org/10.1016/S0031-0182(00)00035-3, 2000.
Schulz, M. and Mudelsee, M.: REDFIT: estimatingred-noise spectra directly from unevenly spaced paleoclimatic time series, Comput. Geosci., 28, 421-426, 2002.

Shackleton, N. J. and Hall, M. A.: Oxygen and carbon isotope stratigraphy of the deep sea drilling project hole 552A: PlioPleistocene glacial history, Initial Reports DSDP, 81, 599-609, https://doi.org/10.1029/2000PA000513, 1984.

Stow, D. A.V., Hernández-Molina, F. J., and AlvarezZarikian, C.: Expedition 339 Summary, edited by Expedtion 339 Scientists, Exped. 339 Summ., Proceeding(339), https://doi.org/10.2204/iodp.proc.339.104.2013, 2013.

Torrence, C. and Compo, G. P.: A Practical Guide to Wavelet Analysis, Bull. Am. Meteorol. Soc., 79, 61-78, https://doi.org/10.1175/15200477(1998)079<0061:APGTWA>2.0.CO;2, 1998.

Toucanne, S., Mulder, T., Schönfeld, J., Hanquiez, V., Gonthier, E., Duprat, J., Cremer, M., and Zaragosi, S.: Contourites of the Gulf of Cadiz: A high-resolution record of the paleocirculation of the Mediterranean outflow water during the last 50,000 years, Palaeogeogr. Palaeoclimatol. Palaeoecol., 246, 354-366, https://doi.org/10.1016/j.palaeo.2006.10.007, 2007.

Verhallen, P. J.: Late Pliocene to Early Pleistocene Mediterranean mud-dwelling foraminifera: influence of a changing environment on community structure and evolution, Utrecht Micropaleontol. Bull., 40, 220 pp., 1991.

Voelker, A., Lebreiro, S., Schonfeld, J., Cacho, I., Erlenkeuser, H. and Abrantes, F.: Mediterranean outflow strengthening during northern hemisphere coolings: A salt source for the glacial Atlantic?, Earth Planet. Sci. Lett., 245, 39-55, https://doi.org/10.1016/j.epsl.2006.03.014, 2006.

Voelker, A. H. L., Colman, A., Olack, G., Waniek, J. J., and Hodell, D.: Oxygen and hydrogen isotope signatures of Northeast Atlantic water masses, Deep Sea Res. Part II, 116, 89-106, https://doi.org/10.1016/j.dsr2.2014.11.006, 2015.

Weaver, P. P. E. and Clement, B. M.: Magnetobiostratigraphy of planktonic foraminiferal datums: Deep Sea Drilling Project Leg 94, North Atlantic, vol. 94, U.S. Government Printing Office, 1987.

Zachariasse, W. J., Gudjonsson, L., Hilgen, F. J., Langereis, C. G., Lourens, L. J., Verhallen, P. J. J. M., and Zijderveld, J. D. A.: Late Gauss to Early Matuyama invasions of Neogloboquadrina Atlantica in the Mediterranean and associated record of climatic change, Paleoceanography, 5, 239-252, https://doi.org/10.1029/PA005i002p00239, 1990.

Zahn, R., Sarnthein, M., and Erlenkeuser, H.: Benthic isotope evidence for changes of the Mediterranean outflow during the Late Quaternary, Paleoceanography, 2, 543-559, https://doi.org/10.1029/PA002i006p00543, 1987.

Zijderveld, J. D. A., Hilgen, F. J., Langereis, C. G., Verhallen, P., and Zachariasse, W. J.: Integrated magnetostratigraphy and biostratigraphy of the upper Pliocene-lower Pleistocene from the Monte Singa and Crotone areas in Calabria, Italy, Earth Planet. Sci. Lett., 107, 697-714, 1991. 